\title{
The Mineralization and Structural Geology of the Porphyry Copper Deposits of Pakistan
}

\author{
Syed Tallataf Hussain Shah ${ }^{1 *}$, Nangyal Ghani Khan ${ }^{1}$, Muhammad Imran Hafeez Abbasi ${ }^{1}$, \\ Kamran Tabassum ${ }^{1}$, Syed Khaizer Wahab Shah ${ }^{1}$
}

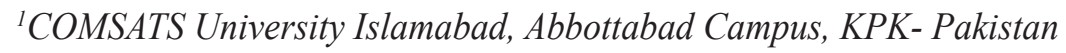

\author{
*CORRESPONDENCE: \\ Syed Tallataf Hussain Shah \\ COMSATS University Islamabad, Abbottabad \\ Campus, KPK- Pakistan \\ Email: tallataf@cuiatd.edu.pk
}

ISSN : 2382-5359(Online), 1994-1412(Print)

DOI:

https://doi.org/10.3126/njst.v20i1.39449

\section{ACCESS THE ARTICLE ONLINE}

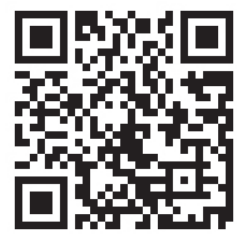

\section{CONFILICT OF INTEREST: None}

Copyright: The Author(s) 2020. This is an open access article under the $\underline{\mathrm{CC}} \mathbf{B Y}$ license.

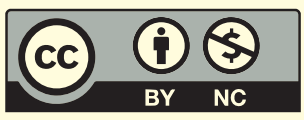

\begin{abstract}
The purpose of this review is to shed light on copper deposits found in different regions of Pakistan. The geological attributes of copper deposits have been considered with their tectonic context. The porphyry copper deposits can be traced in Pakistan from the north through Kohistan Island Arc (KIA) up to the south to Chaghi Magmatic Arc (CMA). These deposits are mainly found in and around the Late Tertiary-Early Tertiary Himalayan Belt, Kohistan magmatic arc, Karakorum Block Foreland fold and thrust belt, Ophiolite Thrust belt, Suture zone and Chaghi Magmatic Arc. These deposits in Pakistan are chiefly established in different episodes of tectonic regimes, including subduction processes, oceanic island arc, continental $\operatorname{arc}_{2}$ along with Chaman- OrnachNal Fault system and post-collisional settings.
\end{abstract}

Keywords: Minerals, porphyry copper deposits, economic geology, Pakistan, Himalayan ranges

\section{INTRODUCTION}

Copper is a metal named after Cyprus, as it was mined from there mainly in the Roman Empire Era (Rickard 1932). Copper has been used in one of the oldest known civilizations and is said to be discovered in $8700 \mathrm{BC}$, as per old traces of copper found in the Middle East in northern Iraq (Hesse 2007). Copper is generally found in the Earth's crust with a concentration of about $50 \mathrm{ppm}$ (Romano and Matteucci 2007). It can also be formed within the continental arcs, where the crustal thickness is greater and deep fractionation (Lee \& Tang 2020). Since the convectional currents within the Earth's interiors are the major driving forces behind the plate tectonics, and the resultant of the sea-floor spreading and plate subduction, which are the significant sources for pragmatic and also a tentative slant for the development of the copper deposits in the Earth (Dietz 1961; Guild 1971; Sillitoe 1972).

The presence of the porphyry copper structures extends between the plutonic and volcanic rocks (Sillitoe 1973). Plate tectonics seems to have a clear association with copper deposits forming due to its high-grade thermal and stress energies, resulting from either direct volcanism or metamorphism. Metasomatism resulting in hydrothermal fluids can also result in the formation of copper deposits. The copper mineralization can be associated with both intrusive and extrusive 
rocks, including porphyry stocks, rhyolites, batholiths and volcanic breccias/veins (Malkani 2015). The copper deposits are chiefly originated either through the PorphyryCopper-System (PCS) in the continental crust or through the Volcanogenic-Massive-Sulphide (VMS) deposits in the oceanic crusts (Sillitoe 1972; Spiess et al. 2007). Copper exists in different varieties in nature with its association with different minerals, resulting in native copper, copper sulfides, and energized copper (Rehman et al. 2019).There are massive copper deposits in the United States, Papua New Guinea, Chile, Indonesia, Australia, and Peru. The porphyry copper deposits of Central-Asia have appeared to be one vital porphyry copper belts of the World (Seltmann \& Porter 2005; Yakubchuk 2005; Yang et al. 2012).

Pakistan is hosting a wide variety of mineral deposits due to its complex geology and tectonics (Shah et al. 2018b, 2019; Shah \& Khan 2004). The principal resources of copper in Pakistan are estimated to be around 6.72 billion tons (Jiskani et al. 2020; Shah 2018). In Pakistan, the copper deposits are majorly centralized to the ophiolitic thrust belts and suture zones, including Kohistan Island Arc (KIA), Karakoram Block (KB) in the north and in the south till Chaghi Magmatic Arc (CMA) (Figure 1) (Kazmi \& Jan 1997). The rock deposits from the Saindak area of the CMA are majorly characterized as monzodiorite and granodiorite, ages of around 22-24 Ma (Malkani 2020; Mastoi et al. 2020). CMA and consistent porphyry copper mineralization took place during the last 55 million years (Perelló et al. 2008).From Gilgit Baltistan, the copper-rich mineral identified as malachite was reported by Hafeez et al.(2020). However, mainly surface mining is being used for copper extraction in Pakistan (Ali \& Rehman 2020). Copper is commonly used for electrical appliances, wires, roofing for weatherproof material, plumbing, jewelry, utensils, nutritional supplements and industrial machinery (Adelstein \& Vallee 1961; John 2003; Kundig and Joseph 1998; Pops 2008; Russell et al. 2001).

\section{GEOLOGICAL SETTINGS}

Geologically Pakistan lies in the territory of three main tectonic plates (Indian, Eurasian \& Arabian Plate). About 200 million years ago, Indian and Arabian plates were the part of supercontinent Gondwana, while the Eurasian plate was the part of supercontinent Laurasia (Bhatti et al. 2018; Shah et al. 2018 a,b,c). About 180 million years ago in the Early Jurassic era, the splitting in the supercontinent Gondwana began (Jokat et al. 2003). In the early Cretaceous age, the Indian plate has undergone separation from Madagascar and started a movement towards the north at a rapid pace (Gnos et al. 1997; Scotese et al. 1988). During the Eocene era, the Indian plate collided with the Eurasian plate (Scotese et al. 1988). However, before the collision, it resulted in the closing of the Neo-Tethys ocean in the north and generation of the Indian Ocean to its south (Shah et al. 2018). The great Himalayan thrust and fold belt were generated as an upshot of the continent-continent collision between the Indian and Eurasian plates. As an outcome of the Indian-Eurasian plate collision, deep and steeply dipping faults were formed along with the Tethys terrain's anterior parts. Massive mélanges and ophiolites were also abducted along this Tethys terrain.

There are double suture zones exist in northern Pakistan. The northern most is the Shyok Suture Zone (SSZ), along which during the Early Cretaceous times, the oceanic plate of Kohistan Island Arc (KIA) was subducted beneath the Karakoram block of the Eurasian plate (Bhatti et al. 2018; Shah et al. $2018 \mathrm{a}, \mathrm{b}$ ). South to the SSZ is the Indus Suture Zone (ISZ), along which the continental part of the Indian plate began to subduct underneath the KIA in the Early to Mid-Eocene age (Brown \& Ryan, 2011; Searle et al. 1999). In Northern Pakistan, the (ISZ) can be traced EW continuously across the Kohistan area to the Lhasa region (Bhatti et al. 2018; Shah et al. 2018a,b).The Chaman Transform fault is linked with the Indus Suture Zone in its Northwestern segment (Kummel 1970). The tightly folded Cretaceous sediments, massive bodies of ophiolites (Waziristan, Zhob, Bela \& Muslimbagh), and pillow lava are present in the South Indus Suture Zone.

Copper is a metallic mineral that occurs in both sedimentary and volcanic rocks. Copper is closely linked with tectonic activities. Therefore, various copper deposits form near or at major tectonic features, like plate boundaries, rift valleys, and island arcs. Some copper deposits also form in deltaic, shallow marine, and non marine environments (Tourtelot \& Vine 1976).

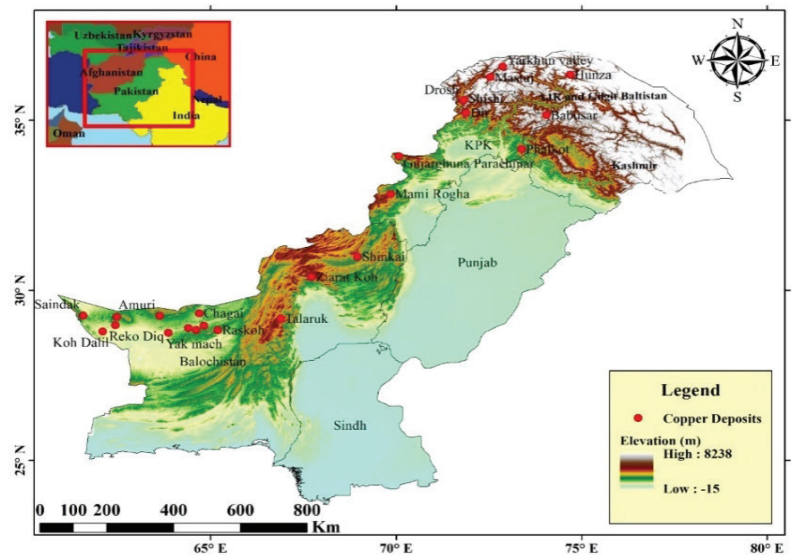

Fig.1: Map showing the main localities of reported copper mineralization in Pakistan. 


\section{THE COPPER DEPOSITS OF PAKISTAN}

Pakistan is situated at the utmost geologically and tectonically dynamic zone of the Indian and Eurasian Plate. The northern portion of Pakistan consists of the collisional belt of Hindukush, Karakoram, and Himalayas (Bhatti et al. 2018; Powell 1979; Shah et al. 2018 a, b). Because of Pakistan's dynamic geotectonic, numerous regional geological features such as the suture zones, arc systems, transform fault zones, subduction zones, and mega thrust systems are present. Pakistan is a miscellaneous focus for the generation of both metallic and non-metallic mineral deposits. Copper is one of such minerals, which is associated mostly with the igneous intrusions and volcanic of the Karakoram block, Magmatic arcs, ophiolitic thrust belts, and suture zones of Pakistan (Kazmi \& Jan 1997).

In Pakistan, the Copper mineralizations existing in Tectono-metallogenic zones are shown in Figure 1, and described as:

\subsection{Himalayan Crystalline Rocks}

In the Himalayas region, the copper deposits are found in veins cutting the Precambrian metasedimentary rocks and associated with Early to Late Tertiary granites and diorites (at Babusar area). At the Phalkot region, it is found in the veins cutting the Hazara Formation, While in Galdanian, it is present in sandstone associated with hematite deposits (Ahmad 1969).

\subsection{Foreland Fold and Thrust Belt}

In Foreland FTB, the copper deposits are reported in sandstones of Warcha and Sardai formations as disseminated nodules along with the Nilawahan gorge, Katha, Musakhel, and Warcha (Ahmad 1969; Memon 1965; Qureshi 1980).

\subsection{Ophiolitic Thrust Belt}

The Geological Survey of Pakistan reported a considerable amount of copper sulfides during their exploration from the Bela ophiolite zone in early 1970. The copper is commonly intercalated in the Bela ophiolites basalt units (Zaigham \& Mallick 2000).

\subsection{Ophiolitic Thrust Belt and Suture Zone}

Within the ophiolites of Shinkai and adjacent Khost suture zone, the copper deposits are related to the Waziristan volcanic and mélanges (Badshah 1985; Beck et al. 1995; Robinson et al. 2000). In Sange gar, Zizha, Otman, Nasai of Zhob, mélanges are linked with ultramafic rocks having chromite deposits (Ahmad 1969; Badshah 1983). The
Bela ophiolitic zone is resulted in a convergence between the Indian plate and the Neo-Tethyan oceanic plate also contains copper deposits (Zaigham \& Mallick 2000).

\subsection{Kohistan IslandArc (KIA)}

The mineralization is found in the meta-volcanic existing in the Bagrot Nala region (Kazmi \& Jan 1997; White 1975). In Nomal village (16 km from Gilgit), the deposits are reported along the Hunza river bank in a yellow mass of extensively weathered rocks at the contact of metavolcanics and granodioritic rocks (Kazmi 1951b; Kazmi \& Jan 1997). The deposits are also reported at Matum-Das having similar geological settings to Nomal deposits. At Henzel village (located $16 \mathrm{~km} \mathrm{NW}$ of the Gilgit city), the deposits are reported along with the intrusions of granite at the faulted contact of biotite schist and marble in mineralized quartz veins (Sillitoe 1979). At Sher Qila, the gossan zone of approximately $100 \mathrm{ft}$ thick in metavolcanic besides granitic intrusions are reported (Kazmi \& Jan 1997). At Singal locality, the deposits are found in quartz vein intrusions in granite rocks along the minor faults (Sillitoe 1979). At Nlizbar valley, the mineralization has been reported in the Darkot group's meta-sediments in ten Sulphide zones along the Main Karakorum Thrust (MKT) (Kazmi 1951a). In areas of KaldamGol, Shishi, DroshGol, GawuchGol, and LalQila of Drosh Valley, different Copper ores have been documented through random sampling locality of MKT through volcanic and meta-sedimentary rocks. The mineralization is reported in the form of disseminated ore bodies or gash veins. The MKT stretches through the area of Shishi-river, which comprises ophiolites and mélanges, and it is in contact in the north with the plutonic rocks of Kesu-Buni zone of the Karakoram block (Ahmad et al. 1969; Pudsey et al. 1985).

\subsection{Karakoram Block (KB)}

In the vicinity of Yarkhun Valley, the ranges of Chapachirag. Chapali, Pakhturi, and Rain host the copper deposits in the form of the disseminated ore bodies, quartz vein, and along the contact zones of shale, quartzite, and limestone (Ahmad 1969; Ali1950). At Imirdin, the deposits are reported in quartz veins and as stringers in quartzite and slate. At Madashit, these are reported in Phyllite and phyletic dolomite in quartz veins and mineralization along the faults. In Shoghot village's locality, these are found in the gossip zones bounded by dissimilar parallel faults, namely, Reshun and Pasti fault. At Prince Burhanuddin and KukilGahirat, the deposits are found in Chitral slates ruptures in the form of mineralized quartz veins. While at Koghozi, it is scattered ores associated with the small calcite vein lets revealing the alteration zones with malachite 
(Ali 1950).

\subsection{Chaghi Magmatic Arc (CMA)}

At the Saindak alteration zone, the deposits are settled within siltstone, sandstones, and tuff of Amala Formation and hosts the copper deposits in sulfide ore bodies (Waheeduddin Ahmed et al. 1972 Bizenjo 1994; Siddiqui 1996; Sillitoe \& Khan 1977). The Missi, Humai, and KabulKoh host the porphyry-type copper deposits (Ahmed et al. 1972; Islam et al. 1993). The localities of Darband-Chah, Dasht-kain, and Ziarat-Piralso host the porphyry copper deposits associated with the Tonanlite porphyry stocks intruding the batholiths of diorite and monzonite (Islam et al. 1993; Kazmi 1981; Siddiqi 1984; Siddiqui et al. 1987). The Amuri hosts syngenetic Manto-type mineralization, which has disseminated copper deposits in Sinjrani volcanic along the fissures (Ahmad 1975; Sillitoe \& Khan 1977). The locality of Kundi-Baluchap holding cretaceous limestone in contact with granodioritic and dioriticintrusives rocks, which hosts the copper mineralization in contact with metamorphic type chalcopyrite and magnetite deposits (Sillitoe \& Khan 1977). The Ras-Koh region's Bandegan deposit has small chalcopyrite and magnetite deposits in contact with syenodioritic intrusions hosting the copper (Ahmad 1975; White 1975). Koh-e-Maraniand PakusNala deposits have copper mineralization in quartz veins along andesite porphyry and diorite and shear zones at the contact of meta-volcanic diorites (Ahmad 1975; Razique 2001). Copper production from Baluchistan in 2007-08 was reported as 36,583 tons (t) (Islam et al. 2010). Some gold and silver mineralization has also been discovered along with porphyry copper deposits reported by GSP (Ahmad et al. 1986).

\subsection{Dir and Drosh Copper Deposits}

There are significant copper deposits in Dir and Drosh areas of Khyber Pakhtunkhwa (Malkani et al. 2016). SDA (Sarhad Development Authority) has explored a promising deposit of copper in the Bekarari-Rokhan area located NW of the Dir. They have estimated the total reserves of about $45 \mathrm{mt}$ with $0.4-0.6 \%$ of copper (Malkani et al. 2016). The localities which contain copper deposits are the Usheri region, Pana Kot, Mirkhani, and Bekarai-Rokhan of Dir and copper deposits of Drosh are located within 8-10 km of the Drosh town.

\section{PREVIOUS WORK}

Previously, the exploration works were carried out in Pakistan mainly through Satellite imagery, remote sensing, and sample investigation from boreholes. Later the ERTS-
1 imagery has also been used to examine porphyry copper deposits in Baluchistan (Schmidt 1973). Shallow depth geophysical surveys have also been performed in Pakistan for copper exploration. Local-scale electromagnetic surveys were also performed at the Bandegan region near the Chaghi district. The EM survey has also been performed in the Rah Kos region, which provided promising results for the later copper excavation (Ahmad 1969; Ahmed 1964), but these surveys were not appreciated afterward because the technology was not so advanced at that time. Most of the exploration work approved in Pakistan for the copper expedition was preliminary and mainly carried out through obsolete methods, mostly reliant on the local people's hand sampling and verbal statements.

\section{CONCLUSION}

The volcanic and igneous intrusions along the suture zones, Karakoram block, Magmatic arcs, and ophiolitic thrust belts host the copper mineralization in Pakistan. In Pakistan recent and preceding works relied on conventional techniques and advancements in investigation and excavation have been poorly utilized. Whereas, more sophisticated geophysical and geochemical techniques are now employed extensively for the copper exploration. For copper excavation, more recent and sophisticated mechanism should be adopted rather than to rely solely on open pit mining.

It is, therefore, suggested that detailed and composite geophysical, geochemical, and geological work should be carried out in the districts known for copper mineralization. Geophysical approaches such as Electromagnetic (EM), Induced Polarization (IP), and Electric Resistivity (ER) surveys can provide better signatures for copper deposits in the subsurface. These exploration techniques can define the subsurface extension well due to the copper high conductivity, good charge ability and association with sulfide. The integration of the gravity data with borehole data and earlier or recent remote sensing data can also lead to better exploration and tonnage.

\section{ACKNOWLEDGMENT}

We would like to express our special gratitude to the anonymous referees for their valuable suggestions. We especially thank Prof. Dr. Ishtiaq Ahmed Khan Jadoon and Dr. Javaid Tanoli for their valuable input as a part of this project "Mineral deposits of Pakistan". The project is based on documenting the economic resources of Pakistan and therefore this research will act as a new insight for the upcoming researchers. We would also like to thank COMSATS University online library for providing us with 
access to the published and unpublished data used in this manuscript.

\section{REFERENCES}

1. Adelstein, S.J. and B. L. Vallee. 1961. Copper metabolism in man. New England Journal of Medicine, 265(18), 892-897.

2. Ahmad. 1969. Directory of Mineral deposits of Pakistan. GSP, Rec. 15(3): 200Pp.

3. Ahmad, M., R. H. Siddiqui and M. A. Chaudhary. 1986. Geological and geochemical exploration and preliminary evaluation of Dasht-E-Khain porphyry copper-molybdenum prospect, Chagai District, Baluchistan, Pakistan.

4. Ahmad, M., K.S.S. Ali, B. Khan, M.A. Shah and I. Ullah. 1969. The geology of the Warsak area, Peshawar, West Pakistan. Geol. Bull. Univ. Peshawar, 4, 44-78.

5. Ahmad, Z. 1975. Directory of Mineral deposits of Balochistan. GSP, Rec.(36): 178p.

6. Ahmed, W. 1964. Iron-copper deposits of Bandgan, Kimri, and Jadino; Raskoh Range, Chagai district, West Pakistan. Symposium on Mining Geology and the Base Metals, Ankara, Turkey, 181, 90.

7. Ahmed, W., S.N. Khan and R.G. Schmidt. 1972. Geology and copper mineralization of the Saindak Quadrangle, Chagai district, West Pakistan. US Govt. Print. Off..

8. Ali, S.T.T. 1950. Preliminary report on economic mineral occurrences in parts of Lutkho, Turikho, Mulikho and Chitral District, Central State, Geol. Surv. Pak., Open-file report.

9. Ali, D. and A.U. Rehman. 2020. Adoption of autonomous mining system in Pakistan-Policy, skillset, awareness and preparedness of stakeholders. Resources Policy, 68, 101796.

10. Badshah, M.S. 1985. Development potential of Waziristan copper. Record of FATA Development Corporation, Peshawar.

11. Badshah, M.S. 1983. Geology and breccia pipe primary and secondary copper mineralization in Waziristan.

12. Beck, R.A., D.W. Burbank, W.J. Sercombe, G.W. Riley, J. K. Barndt, J.R. Berry, J. Afzal, A.M. Khan, H. Jurgen and J. Metje. 1995. Stratigraphic evidence for an early collision between northwest India and Asia. Nature, 373(6509), 55.
13. Bhatti, Z. I., J. Zhao, N.G. Khan and S.T.H. Shah. 2018. Structure of the crust and upper mantle beneath NW Himalayas, Pamir and Hindukush by multi-scale double-difference seismic tomography. Physics of the Earth and Planetary Interiors, 281, 92-102.

14. Bizenjo, M.Y. 1994. Status and prospects of Saindak copper-gold project. Intern. Round Table Conf. on Foreign Investment in Explore. and Mining in Pakistan. Islamabad, 5p.

15. Brown, D. and P.D. Ryan. 2011. Arc-continent collision. Springer Science \& Business Media.

16. Dietz, R.S. 1961. Continent and ocean basin evolution by spreading of the seafloor. Nature, 190(4779), 854 857.

17. Gnos, E., A. Immenhauser and T.J. Peters. 1997. Late Cretaceous/early Tertiary convergence between the Indian and Arabian plates recorded in ophiolites and related sediments. Tectonophysics, 271(1-2), 1-19.

18. Guild, P.W. 1971. Metallogeny: a key to exploration. Mining Engineering, 23(1), 69-72.

19. Hafeez, M., S.A. Abbasi, M. Rafique, R. Hayder, M. Sajid, J. Iqbal, N. Ahmad and S. Shahida. 2020. Calibration-free laser-induced breakdown spectroscopic analysis of copper-rich mineral collected from the Gilgit-Baltistan region of Pakistan. Applied Optics, 59(1), 68-76.

20. Hesse, R.W. 2007. Jewellerymaking through history: An encyclopedia. Greenwood Publishing Group.

21. Islam, N.U., S.A. Hussain, S.Q. Abbas and M. Ashraf. 2010. Mineral statistics of Pakistan. GSP, Special Issue.

22. Islam, N.U., S.N. Khan and W.M.J. Khan. 1993. Economic mineral deposits of Pakistan. GSP, Unpublished Report.

23. Jiskani, I.M., Q. Cai, W. Zhou and X. Lu. 2020. Assessment of risks impeding sustainable mining in Pakistan using fuzzy synthetic evaluation. Resources Policy, 69, 101820.

24. John, E. 2003. Nature's Building Blocks “An AZ guide to the Elements". 287-293.

25. Jokat, W., T. Boebel, M. König and U. Meyer. 2003. Timing and geometry of early Gondwana breakup. Journal of Geophysical Research: Solid Earth, 108(B9).

26. Kazmi, A.H. 1951a. Notes on the geology and Mineral occurrences in Dainyor and Jotial nalas, NE 
and S of Gilgit. GSP, File, 534, 15.

27. Kazmi, A.H. 1951b. Preliminary report on Geol. and Mineral occurrences in lower Hunza valley. GSP, File, 534(10).

28. Kazmi, A.H. 1981. Stratigraphy And Sedimentation Of The Jurassic In North-Eastern Baluchistan. Journal of Himalayan Earth Sciences, 14.

29. Kazmi, A.H and M.Q. Jan. 1997. Geology and tectonics of Pakistan. Graphic publishers.

30. Kummel, B. 1970. Stratigraphy and palaeontology of the Permian-Triassic boundary beds, Salt Range and trans-Indus ranges, West Pakistan. Stratigraphic Boundary Problems: Permian and Triassic of West Pakistan, 4, 1-110.

31. Kundig, K.J.A. and G. Joseph. 1998. Copper: Its trade manufacture, use, and environmental status.

32. Lee, C.T.A. and M. Tang 2020. How to make porphyry copper deposits. Earth and Planetary Science Letters, $529,115868$.

33. Malkani, M.S. 2015. Stratigraphy, mineral potential, geological history and paleobiogeography of Balochistan Province, Pakistan. Sindh University Research Journal-SURJ (Science Series), 43(2).

34. Malkani, M.S. 2020. Revised Stratigraphy and Mineral Resources of Balochistan Basin, Pakistan: An Update. Open Journal of Geology, 10(07), 784.

35. Malkani, M.S., M.H. Alyani, M. I. Khosa, S. Tariq, F.S. Buzdar, G. Khan and J. Faiz. 2016. Mineral Resources of Pakistan-an update. Lasbela University Journal of Science \& Technology, 5, 90-114.

36. Mastoi, A.S., X. Yang, J. Deng, A.G. Kashani and A.A. Hakro. 2020. Geochronological and geochemical studies of adakites from Tethyan Belt, Western Pakistan: A clue to geodynamics and $\mathrm{Cu}$ $\mathrm{Au}$ mineralization. International Geology Review, 62(10), 1273-1293.

37. Memon. 1965. A brief report on copper showings in Speckled Sandstone near Musakhel (District Mianwali). WPIDC, Unpub Rept.

38. Perelló, J., A. Razique, and J. Schloderer. 2008. The Chagai porphyry copper belt, Baluchistan province, Pakistan. Economic Geology, 103(8), 1583-1612.

39. Pops, H. 2008. Processing of wire from antiquity to the future. Wire J. Int., 41(6), 58-66.

40. Powell, C.M. 1979. A speculative tectonic history of Pakistan and its surroundings. Geodynamics of Pakistan.

41. Pudsey, C.J., M.P. Coward, I.W. Luff, R.M. Shackleton, B.F. Windley and M.Q. Jan. 1985. Collision zone between the Kohistan arc and the Asian plate in NW Pakistan. Earth and Environmental Science Transactions of The Royal Society of Edinburgh, 76(4), 463-479.

42. Qureshi, M.K.A.1980. Copper showing in Warchha Sandstone and Sardhai Formation, Salt Range. Contrib. Geol. Pakistan, 61-87.

43. Razique, A. 2001. Potential of economic porphyry copper-gold deposits in western Chagai magmatic belt, Balochistan. Acta Mineralogica Pakistanica.

44. Rehman, M., L. Liu, Q. Wang, M.H. Saleem, S. Bashir, S. Ullah and D. Peng. 2019. Copper environmental toxicology, recent advances, and future outlook: A review. Environmental Science and Pollution Research, 1-14.

45. Rickard, T.A. 1932. The nomenclature of copper and its alloys. The Journal of the Royal Anthropological Institute of Great Britain and Ireland, 62, 281-290.

46. Robinson, J., R. Beck, E. Gnos and R.K. Vincent. 2000. New structural and stratigraphic insights for northwestern Pakistan from field and Landsat Thematic Mapper data. Geological Society of America Bulletin, 112(3), 364-374.

47. Romano, D., and F. Matteucci. 2007. Contrasting copper evolution in $\omega$ Centauri and the Milky Way. Monthly Notices of the Royal Astronomical Society: Letters, 378(1), L59-L63.

48. Russell, R.M., J. L. Beard, R.J. Cousins, J.T. Dunn, G. Ferland, K.M. Hambidge, S. Lynch, J.G. Penland, A.C. Ross and B. J.Stoecker. 2001. Dietary reference intakes for vitamin A, vitamin $\mathrm{K}$, arsenic, boron, chromium, copper, iodine, iron, manganese, molybdenum, nickel, silicon, vanadium, and zinc. A Report of the Panel on Micronutrients, Subcommittees on Upper Reference Levels of Nutrients and Interpretation and Uses of Dietary Reference Intakes, and the Standing Committee on the Scientific Evaluation of Dietary Reference Intakes Food and Nutrition.

49. Schmidt, R. G. 1973. Use of ERTS-1 images in the search for porphyry copper deposits in Pakistani Baluchistan.

50. Scotese, C.R., L.M. Gahagan and R.L. Larson. 1988. 
Plate tectonic reconstructions of the Cretaceous and Cenozoic ocean basins. Tectonophysics, 155(1-4), $27-48$.

51. Searle, M.P., M.A. Khan, J.E. Fraser, S.J. Gough and M.Q. Jan. 1999. The tectonic evolution of the Kohistan-Karakoram collision belt along the Karakoram Highway transect, north Pakistan. Tectonics, 18(6), 929-949.

52. Seltmann, R. and T.M. Porter. 2005. The porphyry $\mathrm{Cu}-\mathrm{Au} / \mathrm{Mo}$ deposits of Central Eurasia: 1. Tectonic, geologic and metallogenic setting and significant deposits. Super Porphyry Copper and Gold Deposits: A Global Perspective, 2, 467-512.

53. Shah, S.T.H., J. Zhao, B. Upendra, N.G. Khan and Z.I. Bhatti. 2018a. Indian-Eurasian collision, structure, and convergence in the western Himalayan syntaxis along Pamir-Tajikistan -A short review, in Proceedings International Research Journal of Earth $\mathrm{S}$.

54. Shah, S.T.H., J. Zhao, Q. Xiao, Z.I. Bhatti, N.G. Khan, H. Zhang, G. Deng and H. Liu. 2018b. Electrical resistivity structures and tectonic implications of Main Karakorum Thrust (MKT) in the western Himalayas: NNE Pakistan: Physics of the Eart.

55. Shah, S.T.H., M. Tariq, N.G. Khan, F.u.R. Qaiser, A. Iftikhar, A. Farid and N. Shah. 2019. Chromite deposits of Pakistan: A short review: International Journal of Research- Granthaalayah, v. 7, no. 7, p. $70-78$.

56. Shah, M.T., and H. Khan. 2004. Exploration and extraction of placer gold in the terraces of Bagrot valley, Gilgit, northern Pakistan. Geological Bulletin, University of Peshawar, 37, 27-40.

57. Shah, S.A.H. 2018. Strategy for Mineral Sector Development in Pakistan.

58. Shah, S.T.H., J. Zhao, Q. Xiao, Z.I. Bhatti, N.G. Khan, H. Zhang, G. Deng and H. Liu. 2018c. Electrical resistivity structures and tectonic implications of Main Karakorum Thrust (MKT) in the western Himalayas: NNE Pakistan. Physics of the Earth and Planetary Interiors, 279, 57-66.

59. Siddiqui, R.H. 1984. Petrographic and ore microscopic study of Dasht-e-Kain porphyry coppermolybdenum prospect, Chagai District, Balochistan, Pakistan. GSP, IR, 213, 26p.
60. Siddiqui, R.H. and J.M. Mengal. 1987. Paragenetic and petrochemical study of piiyllic alteration at Dasht-e-Kain porphyry Cu-Mo prospect, Baluchistan, Pakistan.. Acta Mineralogica Pakistanica, 3, pp. I28133.

61. Siddiqui, R.H. 1996. Magmatic evolution of ChagaiRaskoh arc terrane and its implication for porphyry copper mineralization. Geologica, 2, 87-119.

62. Sillitoe, R.H., and S.N. Khan. 1977. Geology of saindak porphyry copper deposit, Pakistan.

63. Sillitoe, R.H. 1972. A plate tectonic model for the origin of porphyry copper deposits. Economic Geology, 67(2), 184-197. https://doi.org/10.2113/ gsecongeo.67.2.184

64. Sillitoe, R.H. 1973. The tops and bottoms of porphyry copper deposits. Economic Geology, 68(6), 799-815.

65. Sillitoe, R.H. 1979. Speculations on Himalayan metallogeny based on evidence from Pakistan. Geodynamics of Pak. GSP, Quetta, 167-179.

66. Spiess, V., L. Baumann, M. Bruning, and G. Collins. 2007. Cold seeps of the Makran subduction zone (continental margin of Pakistan). Cruise.

67. Tourtelot, E.B. and J.D. Vine. 1976. Copper deposits in sedimentary and volcanogenic rocks. US Geological Survey.

68. White, M.G. 1975. Copper, lead, zinc, antimony, and arsenic in Pakistan. US Geological Survey.

69. Yakubchuk, A.S. 2005. Gold and base metal metallogeny of the Central Asian orogenic supercollage. Econ. Geol., 100, 1035-1068.

70. Yang, F., J. Mao, F. Pirajno, S. Yan, G. Liu, G. Zhou, Z. Zhang, F. Liu, X. Geng and C. Guo. 2012. A review of the geological characteristics and geodynamic setting of Late Paleozoic porphyry copper deposits in the Junggar region, Xinjiang Uygur Autonomous Region, Northwest China. Journal of Asian Earth Sciences, 49, 80-98.

71. Zaigham, N.A., and K.A. Mallick. 2000. Bela ophiolite zone of southern Pakistan: Tectonic setting and associated mineral deposits. Geological Society of America Bulletin, 112(3), 478-489. 